\title{
Anti-bacterial Effect of Oenothera lamarckiana Aerial Part Extract
}

\author{
Ji Yeong Yang ${ }^{1,2, \$, *}$, Pyoengjae Lee ${ }^{3,, * *}$ and Sa-Hyun $\mathrm{Kim}^{4, ; ; * * *}$ \\ ${ }^{I}$ Department of Biomedical Laboratory Science, College of Health Sciences, \\ Yonsei University, Wonju 26493, Korea \\ ${ }^{2}$ Crop Foundation Division, National Institute of Crop Science, Jeonju 54875, Korea \\ ${ }^{3}$ School of Industrial Bio-pharmaceutical Science, Semyung University, Jecheon 27136, Korea \\ ${ }^{4}$ Department of Clinical Laboratory Science, Semyung University, Jecheon 27136, Korea
}

\begin{abstract}
Ingestion of food contaminated with microorganism, if not always, could lead to severe health problem. Preservatives has been added to food to prevent food from being contaminated with microorganism. But, these have potential to threaten the health. Therefore, much effort has been taken to find the safe materials showing the anti-microbial activity. In this study, we investigated the anti-bacterial activity of Oenothera lamarckiana aerial part extract against eight bacteria strain. In paper disc assay, extract inhibited the growth of Staphylococcus aureus, Methicillin-resistant S. aureus, Bacillus cereus and Shigella dysenteriae at $200 \mu \mathrm{g} / \mathrm{disc}$, but not against Escherichia coli, E. coli O157:H7, Salmonella Typhi and $S$. enteritidis. Minimum inhibitory concentration (MIC) against Staphylococcus aureus, Methicillin-resistant S. aureus, Bacillus cereus and Shigella dysenteriae is $250,250,500$ and $500 \mu \mathrm{g} / \mathrm{mL}$, respectively. Compared with reported MIC of other plant resources, $O$. lamarckiana aerial part extract showed the relatively high anti-bacterial activity. O. lamarckiana aerial part could be suitable for the preservative development. But, it still remains to be studied to evaluate safety and so on.
\end{abstract}

Key Words: Oenothera lamarckianal, Anti-bacterial activity, Staphylococcus aureus, Minimum inhibitory concentration

식중독(food poisoning)은 식품을 매개로 하여 나타나는 질환으로 인체 유해 미생물 혹은 화학물질 등에 오염된 신선식품 혹은 육가공품을 섭취함으로서 나타난다. 미생 물에 의한 식중독은 크게 Staphylococcus aureus와 Bacillus cereus 등의 박테리아를 대표로 하는 장독소 기전을 통한 비염증성 설사를 동반하는 경우와 Salmonella 속 박테리 아를 대표로 하는 장관 침습 혹은 세포독소 기전을 통한 염증성 설사를 동반하는 경우로 나눌 수 있다. 이런 미생 물에 의한 식품오염을 막기 위해 신선식품 혹은 육가공 품의 생산, 가공, 유통 등 소비자에 도달하기 하기 전 과 정에 오염요인 관리하고 좀 더 정교한 미생물 탐색 기술
을 개발하고자 노력하고 있다(Lim and Kim, 2017; Choi et al., 2019). 동시에 식품을 장기간 안전하게 보존하고자 항균 효과를 가지는 식품 보존제를 사용하는데 천연자원의 항 균 활성과 항균물질을 탐색하고 산업적으로 응용하는 방 법에 대한 연구 또한 꾸준히 진행되어 오고 있다(Yang and Lee, 2013; Lee et al., 2015; Lee et al., 2017; Liu et al., 2017; Yu et al., 2019).

Oenothera 속의 달맞이꽃은 남·북 아메리카가 원산지 로 우리나라에서는 전국적으로 자생하나 특히 남부해 안과 제주도에서 주로 찾아볼 수 있다고 알려져 있다. Oenothera 속 달맞이꽃의 생리활성 효능과 관련하여 항산

Received: October 30, 2020 / Revised: December 11, 2020 / Accepted: December 12, 2020

*Graduate student, ${ }^{* *}$ Professor.

${ }^{\S}$ These authors contributed equally.

${ }^{\dagger}$ Corresponding author: Sa-Hyun Kim. Department of Clinical Laboratory Science, Semyung University, Jaecheon 27136, Korea.

Tel: +82-43-649-1624, Fax:+82-50-4411-9604, e-mail: science4us@semyung.ac.kr

(C) The Korean Society for Biomedical Laboratory Sciences. All rights reserved.

@This is an Open Access article distributed under the terms of the Creative Commons Attribution Non-Commercial License (http://creativecommons.org/licenses/by-nc/3.0/) which permits unrestricted non-commercial use, distribution, and reproduction in any medium, provided the original work is properly cited. 
Table 1. List of bacteria used for anti-bacterial effect of $O$. lamarckiana

\begin{tabular}{lllll}
\hline \hline Gram staining & & Media & Temp. \\
\hline \multirow{3}{*}{ Positive } & Staphylococcus aureus & ATCC 25923 & Nutrient agar & $37^{\circ} \mathrm{C}$ \\
& MRSA $^{1)}$ & ATCC 43300 & Nutrient agar & $37^{\circ} \mathrm{C}$ \\
& Bacillus cereus & ATCC 13061 & Nutrient agar & $30^{\circ} \mathrm{C}$ \\
\hline \multirow{5}{*}{ Negative } & Shigella dysenteriae & ATCC 13313 & Nutrient agar & $37^{\circ} \mathrm{C}$ \\
& Escherichia coli & ATCC 25922 & Nutrient agar & $37^{\circ} \mathrm{C}$ \\
& Escherichia coli O157:H7 & ATCC 35150 & Nutrient agar & $37^{\circ} \mathrm{C}$ \\
& Salmonella Typhi & ATCC 19430 & Nutrient agar & $37^{\circ} \mathrm{C}$ \\
& Salmonella enteritidis & ATCC 13076 & Nutrient agar & $37^{\circ} \mathrm{C}$ \\
\hline
\end{tabular}

${ }^{1)}$ Methicillin-resistant Staphylococcus aureus

화, 항염증, 항암 등이 보고된 바 있어 산업적으로 이용 가치가 높다고 평가되고 있으며 특히 달맞이꽃의 씨의 생리활성 연구는 매우 활발한 편이다(Yoon et al., 2009; Almora-Pinedo et al., 2017; Timoszuk et al., 2018; Pajak et al., 2019). Oenothera 속 달맞이꽃의 항균 작용과 관련하여 애 기달맞이꽃(Oenothera laciniata) 전초 $80 \%$ 에탄올 추출물 과 분획물이 항균효과를 보였으며(Kim et al., 2007) 달맞이 꽃(Oenothera biennis) $70 \%$ 에탄올 추출물의 경우 S. aureus, E. coli, S. Typhi에 대해서는 성장억제 효과를 보이지 않았 으나 Bacillus cereus에 대해서는 성장억제를 보였다(Kim and Lee, 2016). 긴잎달맞이꽃(Oenothera odorata) 뿌리 75\% 메탄올 추출물과 분획물 대상으로 항균효과 실험했을 때 는 클로로포름 분획물이 Streptococcus 속에 대해 상대적으 로 높은 항균력 보였다(Shin et al., 1994). 하지만 Oenothera 속 달맞이꽃 중 큰달맞이꽃(Oenothera lamarckiana)이 식품 부패 및 식중독 관련 균에 대한 성장억제 효과가 보고된 바 없다. 본 연구는 큰달맞이꽃 지상부 추출물을 대상으 로 항균효과가 있는지 실험하여 식품과 관련하여 효용이 있는지 기초적인 자료를 제시하고자 한다.

큰달맞이꽃(Oenothera lamarckiana)의 지상부 추출물은 한국식물추출물은행에서 구매하여 사용하였다. 추출물은 dimethyl sulfoxide (DMSO)에 녹인 후 분주하여 -20도에서 보관하였다. 실험에 사용한 bacteria에 대한 정보는 Table 1 과 같다. 실험 균주는 보통한천배지(Becton-Dickinson, New Jergy, USA)에 계대 배양하여 사용하였다. $30^{\circ} \mathrm{C}$ 혹은 $37^{\circ} \mathrm{C}$ 에서 18 시간 배양한 세균의 집락을 취하여 멸균 생리식염 수로 옮겨 각각의 균수를 McFarland 탁도 $0.5\left(1.5 \times 10^{8} /\right.$ $\mathrm{mL}$ )에 맞추어 세균 부유액을 준비하였다. Muller-Hinton 평판배지(Becton-Dickinson) 표면에 멸균된 면봉을 이용하 여 세균 부유액을 3 회 반복하여 도말하였다. DMSO에
Table 2. Clear zone (mm) of treatment with $O$. lamarckiana against bacteria

\begin{tabular}{lllr}
\hline \hline \multirow{2}{*}{$\begin{array}{l}\text { Gram } \\
\text { staining }\end{array}$} & \multicolumn{1}{c}{ Strain } & \multicolumn{2}{c}{$\begin{array}{c}\text { Concentration } \\
(\mu \mathrm{g} / \mathrm{disc})\end{array}$} \\
\cline { 3 - 4 } & & 20 & 200 \\
\hline \multirow{3}{*}{ Positive } & Staphylococcus aureus & $-1)$ & 12 \\
& MRSA $^{2)}$ & - & 12 \\
& Bacillus cereus & - & 8 \\
\hline \multirow{3}{*}{ Negative } & Shigella dysenteriae & - & 15 \\
& Escherichia coli & - & - \\
& Escherichia coli O157:H7 & - & - \\
& Salmonella Typhi & - & - \\
& Salmonella enteritidis & - & - \\
\hline
\end{tabular}

1) No clear zone

${ }^{2)}$ Methicillin-resistant Staphylococcus aureus

녹인 $20 \mathrm{mg} / \mathrm{mL}$ 과 동일 용매로 희석한 $2 \mathrm{mg} / \mathrm{mL} 10 \mu \mathrm{L}$ 를 paper disc $(6 \mathrm{~mm})$ 에 처리한 후 건조하여 용매를 제거하였 다. 대조군으로 DMSO $10 \mu \mathrm{L}$ 를 paper disc에 처리하여 건 조한 것을 사용하였다. Paper disc를 박테리아를 도말한 평 판배지 위에 올려놓고 밀착시켰다. $37^{\circ} \mathrm{C}$ 에서 24시간 동안 배양한 후 disc 주변에 생성된 생육억제환(clear zone)의 지 름을 측정하였다. 배양된 세균의 집락을 취하여 각각의 균수를 최종 $1 \times 10^{5} / \mathrm{mL}$ 가 되도록 Muller-Hinton 액체배 지(Becton-Dickinson, MA, USA)에 세균 부유액을 준비하였 다. 큰달맞이꽃 추출물은 최소 농도 $0.13 \mathrm{mg} / \mathrm{mL}$ 에서 최대 농도 $2 \mathrm{mg} / \mathrm{mL}$ 의 범위 내에서 Muller-Hinton 액체배지에 단계 희석하였다. 대조군과 각 실험군에 동일한 최종 용 매의 양(\%)이 되도록 $\mathrm{DMSO}$ 를 첨가하였다. 농도별 추출 물과 세균 부유액을 96 well plate에 각각 $100 \mu \mathrm{L}$ 씩 분주한 후 18 시간 배양하였다. 최소억제농도(MIC)는 $600 \mathrm{~nm}$ 에서 

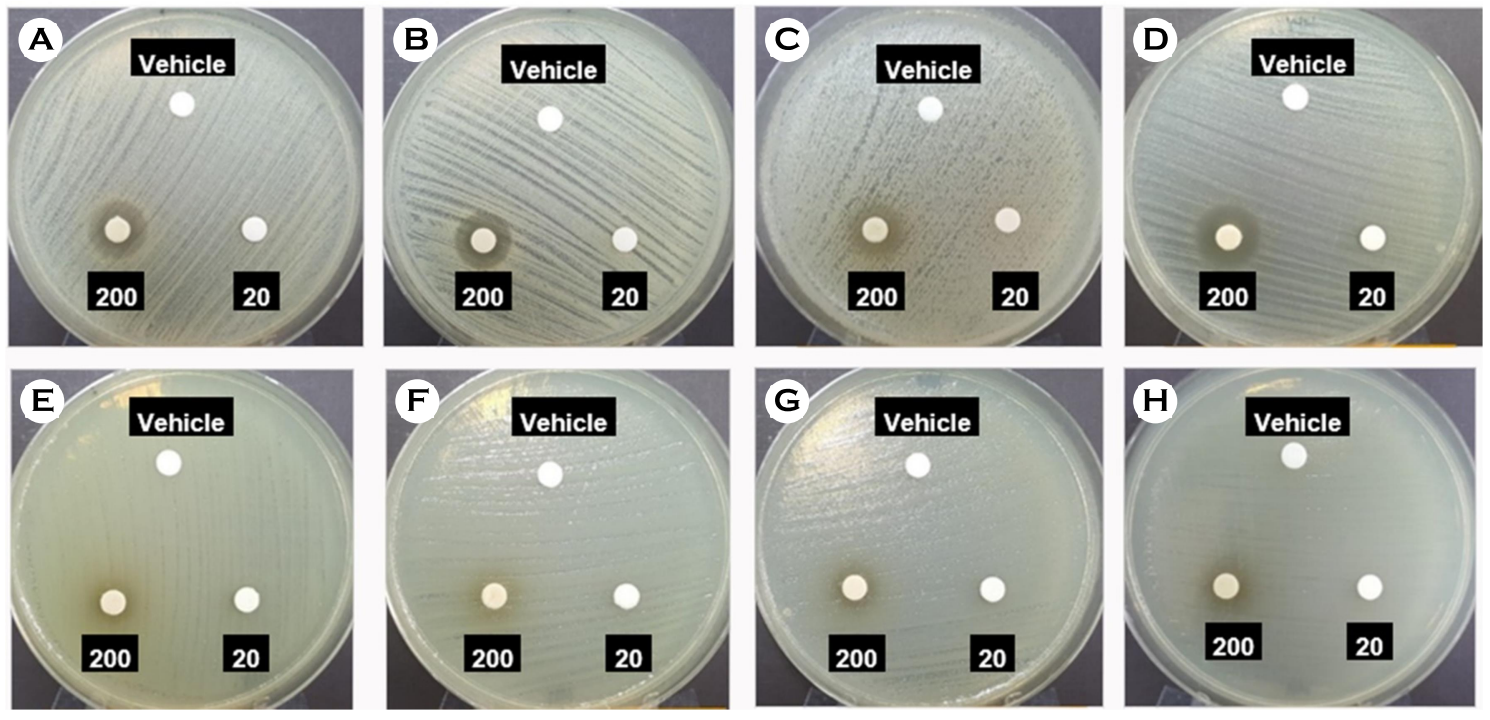

Fig. 1. Anti-bacterial effect of $O$. lamarckiana against S. aureus (A), MRSA (B) and B. cereus (C) and S. dysenteriae (D), E. coli (E), E. coli 0157 (F), S. Typhi (G), S. enteritidis (H). Vehicle: Disc which was added with DMSO, 200: $200 \mu \mathrm{g} / \mathrm{disc}, 20: 20 \mu \mathrm{g} / \mathrm{disc}$.

A

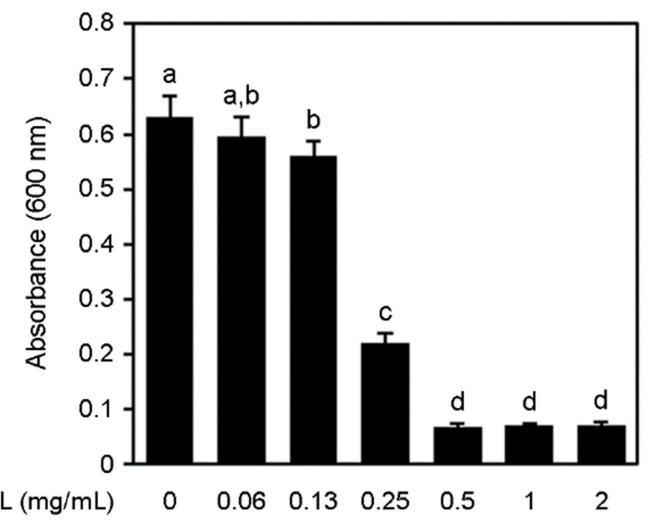

C

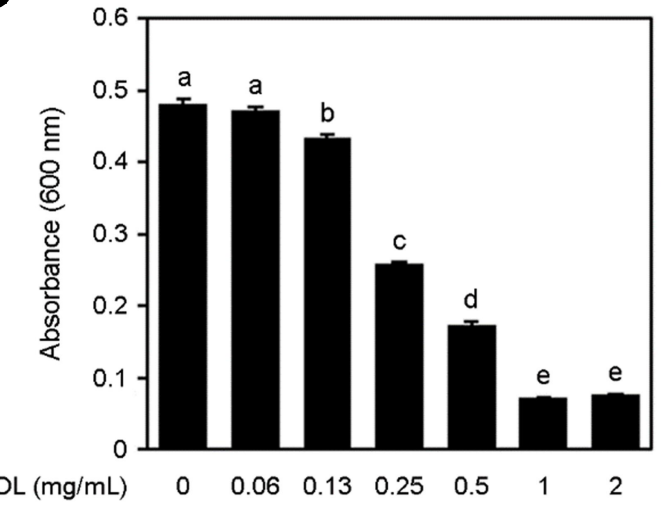

B

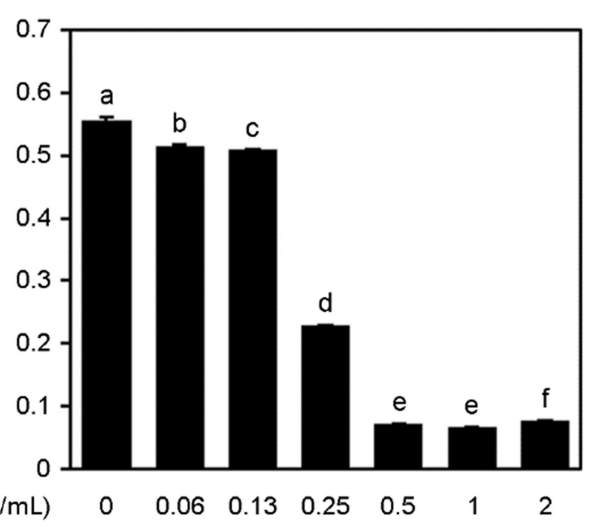

D

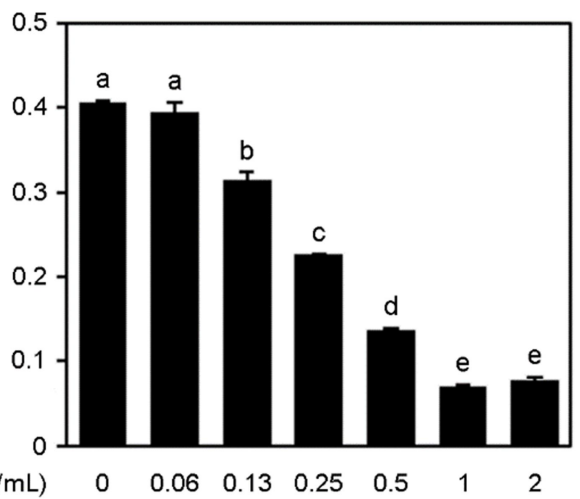

Fig. 2. Determination of the MIC of $O$. lamarckiana extract against $S$. aureus (A), MRSA (B) and B. cereus (C) and $S$. dysenteriae (D) by broth dilution test. A final optical density of the bacterial suspension was measured at $600 \mathrm{~nm}$ wavelength by spectrophotometry. DATA are presented as mean $\pm \mathrm{SD}$ of three independent experiments. Means with different letters indicate the statistical difference $(P<0.05)$. 
흡광도를 측정하여 균 증식의 억제가 일어나는 최소 농 도로 결정하였다. 큰달맞이꽃 추출물을 $0.06,0.13,0.25$, $0.5,1,2 \mathrm{mg} / \mathrm{mL}$ 농도가 되도록 Mueller Hinton 액체배지에 희석한 후 $2 \times 10^{5} / \mathrm{mL}$ 로 희석된 세균을 각각 $100 \mu \mathrm{L}$ 씩 96 well plate에 접종하였다. $37^{\circ} \mathrm{C}$ 의 배양기에서 배양하면서 배양 직후부터 18 시간 후까지 매 2시간마다 $600 \mathrm{~nm}$ 에서 흡광도를 측정하였다. 대조군은 순수한 액체배지에 세균 을 접종한 후 실험군과 동일한 방법으로 배양하면서 측 정하였다. 측정값은 독립적으로 이루어진 3회의 실험에 서 얻은 값을 mean $\pm \mathrm{SD}$ 로 나타내었다. 시료들 간의 통 계분석은 GraphPad Prism 6을 이용하여 일원분산분석과 turkey's multiple comparisons로 이뤄졌다 $(P<0.05)$.

Paper disc assay에서 O. biennis 전초 건조물의 $70 \%$ 에탄 올 추출물이 B. cereus에 대해서는 항균효과를 보였으나 $S$. aureus, E. coli 및 S. Typhimurium에 대해서는 항균효과를 이지 않은 것으로 보고된 바 있으며(Kim and Lee, 2016) $O$. laciniata 전초의 $80 \%$ 에탄올 추출물 및 분획물의 경우 에틸아세테이트 분획물이 B. cereus, L. monocytogenes, $S$. aureus, E. coli, S. enteritidis, S. Typhimurium에 대해 가장 강력한 항균력을 보였다(Kim et al., 2007). 본 연구에서 O. lamarckiana 지상부의 메탄올 추출물은 $20 \mu \mathrm{g} / \mathrm{disc}$ 에서 실험 대상이 된 박테리아에 대해 clear zone을 보이지 않 았지만 $200 \mu \mathrm{g} / \mathrm{disc}$ 에서 $S$. aureus, MRSA, B. cereus와 $S$. dysenteriae에 대해 각각 $12,12,8,15 \mathrm{~mm}$ 의 clear zone을 보였다(Table 2, Fig. 1). Oenothera 속 달맞이꽃의 종, 부위, 추출 용매 등의 조건에 따라 항균의 양상이 다르게 나타 날 수 있음을 보여준다. 좀 더 종합적으로 종별, 부위별, 추출방법별로 비교하여 실험이 이뤄져야 할 것으로 생각 한다.

O. lamarckiana 지상부의 메탄올 추출물은 S. aureus와 MRSA에 대해 $125 \mu \mathrm{g} / \mathrm{mL}$ 에서는 성장억제가 뚜렸하지 않 았으나 $250 \mu \mathrm{g} / \mathrm{mL}$ 에서는 대조군 대비하여 $50 \%$ 이상 성 장을 억제하여 $\mathrm{MIC}$ 는 $250 \mu \mathrm{g} / \mathrm{mL}$ 로 생각되며 S. auresu와 MRSA간의 큰 차이는 보이지 않았다(Fig. 2 and 3). B. cereus와 S. dysenteriae에 대해서는 농도의존적으로 성장 을 억제하는 양상을 보였다(Fig. 2 and 3). S. aureus에 대해
A

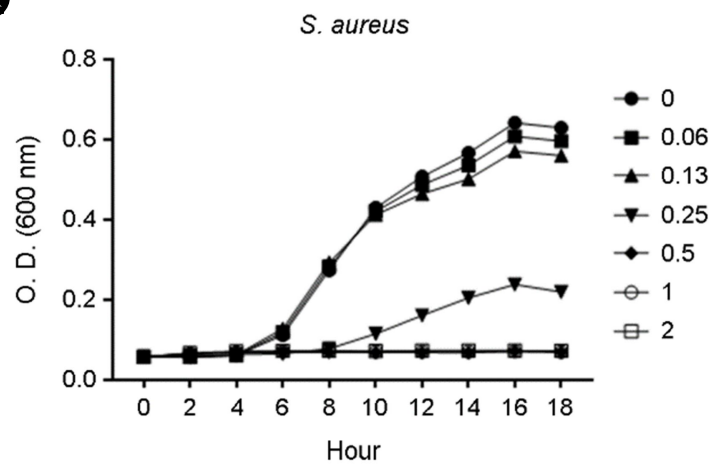

C

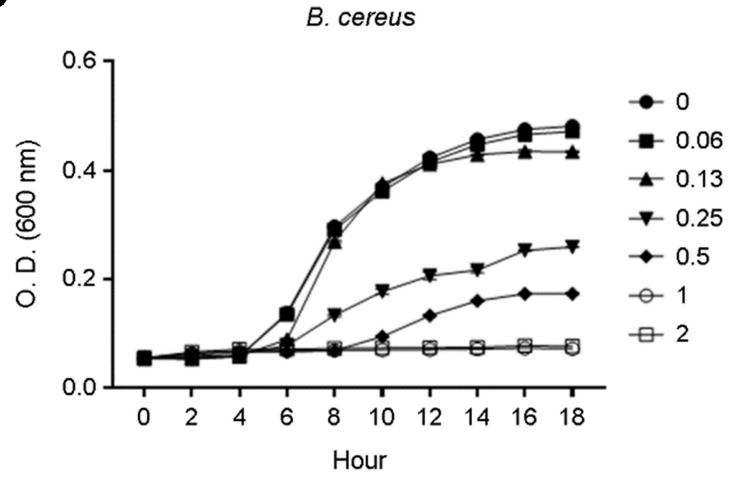

B

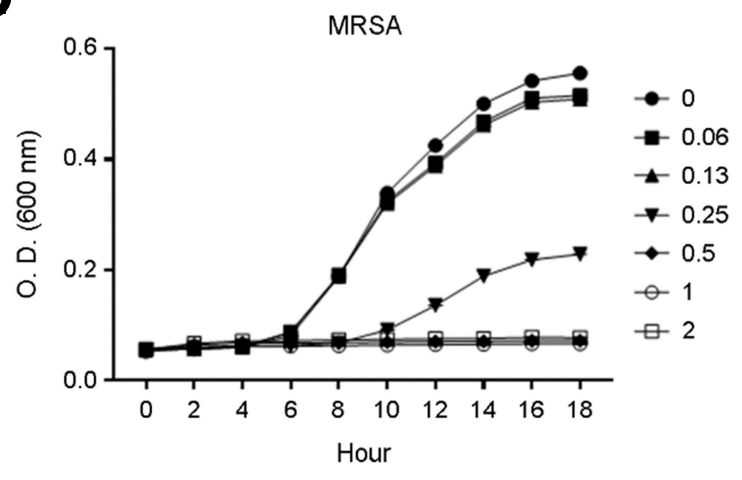

D

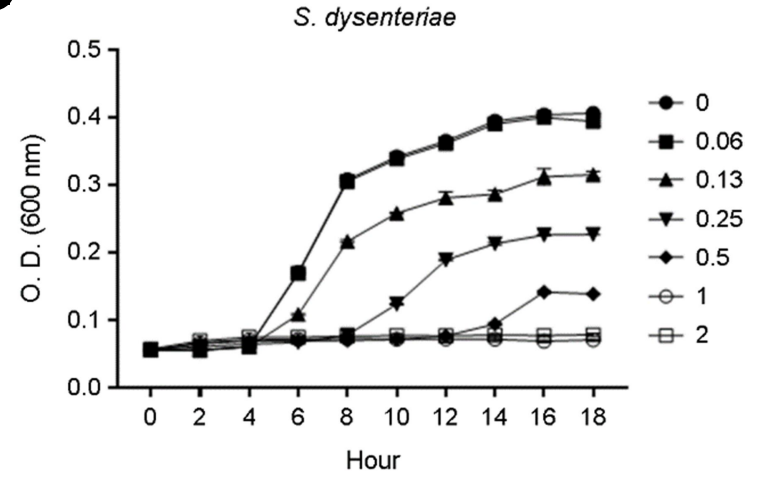

Fig. 3. Growth curves of S. aureus (A), MRSA(B), B. cereus (C) and S. dysenteriae (D). Cultred at different concentration of O. lamarckiana. Bacterial growth was analyzed at the indicated time points by measuring values of $600 \mathrm{~nm}$ wavelength by spectrophotometry. 
생약재 추출물 중 우슬의 $\mathrm{MIC}$ 는 $156.25 \mu \mathrm{g} / \mathrm{mL}$, 목단피와 항백은 $625 \mu \mathrm{g} / \mathrm{mL}$ (Cai et al., 2002). 지유는 $2.5 \mathrm{mg} / \mathrm{mL}$ (Park et al., 2001), 발효 강황은 $0.5 \sim 1 \mathrm{mg} / \mathrm{mL}$ (Ra and Kim, 2016) 이어서 O. lamarckiana 지상부의 메탄올 추출물의 S. aureus 와 MRSA에 대한 항균력은 비교적 뛰어난 것으로 보인 다. Kim et al. (2007)은 O. laciniata 전초 에틸아세테이드 분획물의 S. aureus에 대한 $\mathrm{MIC}$ 가 $10 \mu \mathrm{g} / \mathrm{mL}$ 로 보고한 바 있어 O. lamarckiana 지상부 추출물의 분획물이 좀 더 강 력한 항균효과를 보일 수도 있어 이에 대한 연구가 필요 할 것으로 보인다.

미생물에 오염된 식품의 섭취는 식중독과 같은 질병의 원인이 되기 때문에 식품의 장기 보관 및 유통을 위해 미 생물의 성장을 억제하는 식품보존제의 개발은 국민들의 안전에 크게 기여할 수 있다. 본 실험에서 Oenothera 속 달맞이꽃 중 큰달맞이꽃(Oenothera lamarckiana)의 지상부 메탄올 추출물이 식품에 의한 감염질환과 관련 있는 박테 리아 중 S. aureus, MRSA, B. cereus, S. dysenteriae에 대해 성 장저해효과가 있음을 관찰하였다. 특히 S. aureus, MRSA 에 대해서는 다른 식물의 총 추출물에 대해 상대적으로 강한 성장억제력을 보였다. 따라서 큰달맞이꽃 추출물에 항균력을 보이는 성분이 있을 것으로 생각된다. 이 실험 은 큰달맞이꽃의 항균력에 관한 기초실험으로 향후 큰달 맞이꽃에서 항균효과를 갖는 단일물질 탐색되어 식품의 보관 및 유통에 활용할 수 있을 것으로 기대한다.

\section{ACKNOWLEDGEMENT}

This work was supported by Korea Institute of Planning and Evaluation for Technology in Food, Agriculture and Forestry (IPET) through Future Innovation Food Technology Development Program, funded by Ministry of Agriculture, Food and Rural Affairs (MAFRA) (119023-3).

\section{CONFLICT OF INTEREST}

The authors have declared no conflict of interest.

\section{REFERENCES}

Almora-Pinedo Y, Arroyo-Acevedo J, Herrera-Calderon O, Chumpitaz-Cerrate V, Hanari-Quispe R, Tinco-Jayo A, FrancoQuino C, Figueroa-Salvador L. Preventive effect of Oenothera rosea on N-methyl-N-nitrosourea-(NMU) induced gastric cancer in rats. Clin Exp Gastroenterol. 2017. 10: 327-332.
Cai H, Choi SI, Lee YM, Heo TR. Antimicrobial Effects of Herbal Medicine Extracts on Staphylococcus aureus and Escherichia coli O157:H7. Korean J Biotechnol Bioeng. 2002. 17: 537-542.

Choi J, Lee SI, Rackerby B, Moppert I, McGorrin R, Ha SD, Park SH. Potential Contamination Sources on Fresh Produce Associated with Food Safety. J Food Hyg Saf. 2019. 34: 1-12.

Kim JH, Lee SH. Antioxidative and antimicrobial activities of Oenothera biennis extracted by different methods. Korean J Food Preserv. 2016. 23: 233-238.

Kim JY, Lee JA, Pakr SY. Antibacterial Activities of Oenothera laciniata Extracts. J Korean Soc Food Sci Nutr. 2007. 36: 255-261.

Lee JW, Yoon JH, Park JW. Effects of Grapefruit Seed Extract for Antibacterial Activity on the Coated Packaging. Food Eng Prog. 2015. 19: 104-110.

Lee SM, Kim SI, Kang MS, Lee CY, Hwang DY, Lee HS, Kim DS. Evaluation of Antimicrobial Activity of Steamed and Fermented Asparagus cochinchinenesis. Food Eng Prog. 2017. 21: 143-149.

Lim MC, Kim YR. Sample Preparation and Nucleic Acid-Based Technologies for the Detection of Food Borne Pathogens. Food Eng Prog. 2017. 21: 191-200.

Liu Q, Meng X, Li Y, Zhao CN, Tang GY, Li HB. Antibacterial and Antifungal Activities of Spices. In J Mol Sci. 2017. 18: E1263.

Pajak P, Socha R, Broniek J, Krolikowska K, Fortuna T. Antioxidant properties, phenolic and mineral composition of germinated chia, golden flax, evening primrose, phacelia and fenugreek. Food Chem. 2019. 275: 69-76.

Park CG, Bang KH, Lee SE, Cha MS, Sung JS, Park HW, Seong NS. Antibacterial activity from medicinal plant extracts on the Staphylococcus aureus. Korean J Medicinal Crop Sci. 2001. 9: 251-258.

Ra HN, Kim HY. Antioxidant and Antimicrobial Activities of Curcuma aromatica Salisb. with and without Fermentation. Korean J Food Cook Sci. 2016. 32: 299-306.

Shin SJ, Kwon SK, Lee KH, Sung ND, Choi WY. Extraction and Characterization of Antibacterial Components from the Roots of Evening Primrose (Oetnothera odorata Jacquin). J Agri Sci. 1994. 21: 54-59.

Timoszuk M, Bielawska K, Skrzydlewska E. Evening Primrose (Oenothera biennis) Biological Activity Dependent on Chemical Composition. Antioxidants (Basel). 2018. 7: 108.

Yang HR, Lee HS. Antibacterial Activities of Extracts Derived 
from 13 Medicinal Plants against Food-Borne Bacteria. J Agri Life Sci. 2013. 44: 39-42.

Yoon WJ, Ham YM, Yoo BS, Moon JY, Koh J, Hyun CG. Oenothera laciniata inhibits lipopolysaccharide induced production of nitric oxide, prostaglandin E2, and proinflammatory cytokines in RAW264.7 macrophages. J Biosci Bioeng. 2009. 107: 429-438.

Yu JS, Yu NJ, Gim SW, Lee SJ, Kwon GT, Yuk HG. Antimicrobial effect of black raspberry (Rubus occidentalis, Bokbunja) ex- tract against Escherichia coli and Staphylococcus auresu. Korean J Food Preserv. 2019. 26: 360-364.

https://doi.org/10.15616/BSL.2020.26.4.383

Cite this article as: Yang JY, Lee P, Kim SH. Antibacterial Effect of Oenothera lamarckiana Aerial Part Extract. Biomedical Science Letters. 2020. 26: 383-388. 